\title{
The Bright Side of Shiller-Swaps: A Solution to Inter-generational Risk-sharing
}

\author{
Evert Carlsson and Karl Erlandzon \\ Centre for Finance $\&$ Department of Economics, School of Business, Economics and Law ${ }^{1}$
}

Version: 2006-10-24 - $1^{\text {st }}$ draft 2005-08-20

This paper investigates the diversification demand of an agent, who is faced with the alternative to swap aggregate labour-income risk for equity-exposure, through her individual account in a mandatory-pension scheme. The framework for the analysis is a life-cycle model of a borrowing-constrained individual's consumption- and portfolio-choice in the presence of uncertain labour-income and realistically calibrated tax- and pension systems. Pension benefits stem from both defined benefit and notionally defined contributions part, the latter being indexed to stochastic aggregate labour-income. We show that agents, depending on age and swap premium, agents will be either buyers or sellers of such a swap, and that inter-generational risk sharing can therefore be achieved.

Key Words: Life-cycle, portfolio choice, pensions, Shiller-swap.

JEL classification: D91, G11, G23

We would like to thank Tamir Agmon and Gilles Teysierre and participants at the seminars of Centre fo Finance, Goteborg and Mathematical Finance, Perugia for comments and discussions. The usual disclaimer applies. Carlsson and Erlandzon gratefully acknowledge the financial support of the Department of Economics and Centre For Finance. Erlandzon also gratefully acknowledge support from Stiftelsen Bankforskningsinstitutet.

${ }^{1}$ s-mail address: PO Box 640, S-405 30 Göteborg, Sweden; e-mail address:evert.carlsson@cff.gu.se; tel:+46 31773 2556. 


\section{INTRODUCTION}

Mandatory pension schemes have recently been a focus of debate for both politicians and academics (cf. Commission to Strengthen Social Security (2001), Shiller (2003a)). Primarily, probably because of the magnitude of the necessary changes in the different existing schemes; in order to rectify previously - too much generosity to older generations, either in the form of too small contributions or too large benefits; relative to the realisation of the assumptions on which these systems were based; which has created an increasing legacy cost for future generations; but also because of the availability of new cost effective techniques for managing individual accounts; and not the least, because of some important new insights into the risk management of large societal risks, (cf. Shiller (2003a)). It is to this last reason for attention into mandatory pensions, to which this paper is oriented.

Shiller (2003b) argues that: "the time when we redesign social security ought to be the time when we carefully consider the fundamental intergenerational risk-management problem and define choices in individual accounts". The inter-generational risk-management problem, can simplistically be thought of as: how to transfer the risks and the benefits between two groups of agents - young and old; where the first group disproportionately have human capital and benefits from labour productivity; whereas the other is primarily a beneficiary of owning real capital and receives return from securities, either directly through private savings or indirectly, via mandatory pensions. Albeit, individual accounts are important as a vehicle for creating the appropriate incentives, by connecting contributions with benefits; individual accounts, are also motivated by the need to tailor exposure and diversify risks that originate from individual differences; in age, wage uncertainty, implicit insurances, preferences, and assets that the individual may have; $c f$. Viceira (2001), who shows that even young individuals may optimally have a lower proportion of risky assets than retireés.

When reforming their pension systems, some countries have introduced a notional—or non-funded—defined contribution system $(N D C)$, with individual accounts, and return indexed to wage growth. This has the benefit to the retireés of giving them a share of future labour productivity, while distributing the volatility in wages to the entire society. The problem with this type of indexation is that it exacerbates the wage-related risk for the younger generation who are already exposed to too much 
of this risk in their human capital.

Risk-sharing can be beneficial for the society in its entirety, Campbell and Nosbusch (2006) found that inter-generational risk-sharing decreased the risk premium. Campbell (2005) discusses a risksharing system, where contributions are negatively correlated with capital returns, which effectively creates a swap- contract between real and human capital. Shiller have in numerous articles ( $c f$. Shiller (1993), Shiller (2003a)) advocated the introduction of a swap that pays the domestic aggregate labour income growth in exchange for risk-free or a global labour income growth.

In this paper we propose an NDC system, which allow the individual some freedom of choice in the allocation of the mandatory savings, while keeping the system for contributions intact. We do this by introducing a swap-contract; where the individual, can choose to enter into a swap, that swaps - aggregate labour income growth in exchange for equity return (henceforth — a Shiller-swap), and thereby addressing the inter-generational risk-management problem. Net positions within the $N D C$ system couldportfolio be zero, leaving assets and liabilities in the system unchanged. Allowing the individual to enter into specific positions of the Shiller-swap, would assuage the consequences of forcing all individuals into one-size-fits-all, in terms of risk and returns characteristics of some of their pension assets. To demonstrate the properties of our proposal, we use a model similar to the life-cycle model of Campbell et al, (2001), (henceforth-CCGM).

Life-cycle models have been used as a tool for explaining the accumulation and distribution of wealth as well as portfolio choice over the life-cycle. For agents with uncertain income and liquidity constraints, savings serve several purposes, e.g. precautionary, retirement and bequest. The importance of each of these motives varies over the life-cycle and will consequently affect both the consumption and portfolio-choice. Over the life-cycle, retirement-savings will typically dominate in absolute size and are to a large extent accumulated in mandatory pension schemes.

In a life-cycle model; the complete market solution, should be to equalise consumption over life throughout an individuals' life while keeping the residual savings in assets (including human capital) optimally diversified. However, adding the constraint of inability to capitalise future income; young individuals will attribute little value to their mandatory pension-savings; since they also face a positive 
earnings profile, (cf. CCGM, Carlsson and Erlandzon (2005)). Furthermore, young adults will also have a disproportionate exposure to human capital; which is the rationale for our proposal, to use the mandatory savings account in order to create a more balanced portfolio.

Not surprisingly, the largest welfare gains would be achieved by allowing the individual to freely determine, when to save and how to allocate the savings. However, we cannot expect "the market", to solve this problem. The fact that most societies require a system with mandatory savings for pensions among consenting adults, and that such systems have existed in many countries for more than a century; is maybe a tribute to the intuition of past politicians into option theory and behavioral finance - modern societies will not permit people to consume too much of their income, and then allow the same individuals to rely on society to care for their pension. The individual preferences and perceived insurances that made it necessary for society to introduce the restriction of mandatory savings, will most likely, also reduce the likelihood of these individuals making spontaneously good choices among various investment alternatives. Government has therefore a rôle to play as an administrator of mandatory pensions, but the design of such systems, should minimize the distortions.

We use the Swedish $N D C$ system as a benchmark against which to measure the potential of our proposal. Sweden was the first country to introduce an $N D C$ system, where contributions are credited to an individual notional account with a return set to aggregate labour income growth. This reform-initiated 1999; has attracted a lot of interest as a potential blueprint for other countries $(c f$. Schieber \& Shoven (1996); Diamond (2002), Holzmann \& Palmer (2006)). Furthermore, the relative simplicity and transparency of both the tax and pension systems also facilitates a realistically calibrated model. Finally, Sweden has a unique availability of high-quality register-based data, which alleviates some of the quality problems that would be associated with survey data. While calibrated on Swedish data and rules for taxes and pensions, there are several similarities to systems in other countries, e.g. Italy and $\mathrm{xxxxx}$.

This paper has its origin in the literature that highlights uncertainty and market incompleteness as important factors in explaining individual choice and welfare. The first papers on this subject came from the consumption literature on buffer-stock saving ( $c f$. Modigliani and Brumberg (1954) and 
Friedman (1957)) and portfolio choice (cf. Samuelson (1969) and Merton (1971)). Deaton (1991), Carroll (1997) and Gourinchas and Parker (2002) created life-cycle models with uncertain wages and borrowing constraints. Cocco et al. (2005) and others extended these models with a portfolio choice between a risk-free and a risky asset. In order to analyse the effects of different pension systems, CCGM added a mandatory pension scheme to the model. They demonstrated a positive welfare effect from a lower pension contribution; due to a postponement of savings until a time when labour incomes are higher. Carlsson and Erlandzon (2005), showed that the wage-indexation of mandatory savings, exacerbothbates the negative welfare effects, especially early in life.

Our model extends the CCGM-model both by including realistically calibrated tax- and pensionsystems and by an additional choice; i.e. we allow the individual to swap some of the aggregate income exposure within the mandatory pension system for equity-risk and -return. The main contribution of this paper is that: we can identify the age, when the individual would be a buyer or seller of a Shiller-swap and estimate the required risk premium to attract both buyers and sellers. We find that the young would be buyers - and then sellers when older - and that this pattern is invariant to individual risk-aversion. Therefore, the objective of societal risk-sharing can be achieved by allowing the individuals to take positions in Shiller-swaps.

The rest of this paper is organised as follows. Section 2 describes the model, while Section 3 demonstrates how the model is calibrated. The results are presented in Section 4. Finally, we end with some concluding remarks in Section 5.

\section{THE MODEL}

\subsection{Individual preferences}

The individual maximises the expected utility over the adult life-cycle, which is divided into preand post-retirement. "Optimization", starts at the age ${ }^{2}$ of $\tau_{0}(20)$, retires at a fixed age $K(65)$, and dies at a maximum age of $T(100)$. We assume that the individual has constant relative risk aversion preferences, on a single non-durable consumption good, $C_{\tau}$.

\footnotetext{
${ }^{2}$ Or at the age of 23 , for those with a university degree.
} 
Individual preferences at time $m$ are defined as

$$
\frac{C_{m}^{1-\gamma}}{1-\gamma}+E_{m} \sum_{\tau=m+1}^{T} \delta^{\tau-m}\left(\prod_{j=m}^{\tau-2} p_{j}\right)\left\{p_{\tau-1} \frac{C_{\tau}^{1-\gamma}}{1-\gamma}+b\left(1-p_{\tau-1}\right) \frac{D_{\tau}^{1-\gamma}}{1-\gamma}\right\}
$$

where $C_{\tau}$ represent consumption at age $\tau, \gamma$ is the coefficient of relative risk aversion, $p_{\tau}$ is the one year age contingent survival probability, $\delta$ is the discount factor, $b$ is the bequest parameter and $D_{\tau}$ is the bequest amount.

\subsection{Labour income}

The labour income process follows Carroll and Samwick (1997). During working life, the individual experiences idiosyncratic as well as common shocks to gross income. The log labour real income $l_{i k \tau}$ prior to retirement, for an individual $i$ belonging to group $k$ is exogenous; i.e. the individual cannot change her labour supply or education to e.g. accomodate income shocks, and given as

$$
l_{i k \tau}=f_{k}\left(\tau, \mathbf{Z}_{i k \tau}\right)+v_{i k \tau}+\epsilon_{i k \tau}
$$

where $f_{k}$ is a function of the individual characteristics ${ }^{3} \mathbf{Z}_{i k \tau}$ as well as an average national labour productivity growth $\mu^{l}, \epsilon_{i k \tau}$ is an idiosyncratic temporary shock distributed as $N\left(0, \sigma_{\varepsilon_{k}}\right)$ and $v_{i k \tau}$ is a random walk

$$
v_{i k \tau}=v_{i k \tau-1}+u_{i k \tau}
$$

The innovation, $u_{i k \tau}$, is divided into a group aggregate $\xi_{k \tau} \sim N\left(0, \sigma_{\xi_{k}}\right)$, which we allow to be correlated with excess returns in the risky asset, and an individual uncorrelated component $\omega_{i k \tau} \sim N\left(0, \sigma_{\omega_{k}}\right)$ as

$$
u_{i k \tau}=\xi_{k \tau}+\omega_{i k \tau}
$$

\footnotetext{
${ }^{3}$ i.e. age, martial status, family size, number and age of children.
} 


\subsection{Present mandatory savings and retirement benefits}

Mandatory pension-savings and retirement benefits are part of an NDC-system in which $16 \%$ of gross pre-retirement income ${ }^{4}$ is contributed by the employer and accounted for in individual accounts. Contributions are capped above an income of $300 \mathrm{KSEK}^{5}$. The return on the accounts- $R_{\tau}^{l}$ is set equal to the national labour income growth, (cf. RFV (2002)).

$$
\begin{gathered}
R_{\tau}^{l}=e^{\mu^{l}+\xi_{\tau}^{A}} \\
N D C_{i \tau}=\left\{\begin{array}{cc}
R_{\tau-1}^{l} \cdot N D C_{i \tau-1}+0.16 \min \left[L_{i \tau}, 300\right] & , \tau<65 \\
R_{\tau-1}^{l} \cdot N D C_{i \tau-1}-P O_{\tau}\left(R_{\tau-1}^{l} \cdot N D C_{i \tau-1}\right) & , \tau \geq 65
\end{array}\right.
\end{gathered}
$$

where $P O_{\tau}$ is the age specific annualised mortality-adjusted payout-function after retirement, and $\mu^{l}$ is the expected national labour income growth aggregated over all groups with noise, $\xi_{\tau}^{A} \sim$ $N\left(-\frac{1}{2} \sigma_{\xi^{A}}^{2}, \sigma_{\xi^{A}}\right)$

Most individuals also have a negotiated supplementary pension, in which the employer compensates for the cap on $N D C$ contributions, by contributing to defined benefit plan. The benefits are constant in real terms and is guaranteed for the remainder of life- depend on the wage at retirement ${ }^{6}$. These company defined benefit plans have a payout of $10 \%, 65 \%$ and $32.5 \%$ of incomes in the intervals $[0,320),[320,850)$, and $[850,1270)$ respectively at retirement.

Payout from this plan during retirement will be denoted $D B P O_{i \tau}$, and its dynamics is

$$
\begin{gathered}
D B P O_{i \tau}=0.1 \min \left[L_{i 64}^{P} ; 320\right]+ \\
0.65 \min \left[\max \left(L_{i 64}^{P}-320 ; 0\right) ; 850-320\right]+ \\
0.325 \min \left[\max \left(L_{i 64}^{P}-850 ; 0\right) ; 1270-850\right],
\end{gathered}
$$

with

\footnotetext{
${ }^{4}$ An additional contribution of $2.5 \%$, can be managed by the individual in a funded account, for simplicity, we disregard this here.

${ }^{5}$ In the following, KSEK - thousands of Swedish Kronor will be omitted. The present exchange rate is circa 7 SEK / USD.

${ }^{6}$ In reality it depends on the wage during the five years prior to retirement. However, modelling this rule correctly would have necessitated additional state variables. We therefore approximate this by only including the permanent income changes until retirement.
} 


$$
L_{i 64}^{P}=e^{f_{k}\left(\tau, \mathbf{Z}_{i k 64}\right)+v_{i k 64}} .
$$

All payouts from the $N D C$ pension plan are forfeited in the event of death and for simplicity, we assume the same for the defined benefit plan.

\subsection{Taxes}

Wage and retirement income $L_{i \tau}$ can be defined as

$$
L_{i \tau}=\left\{\begin{array}{cl}
e^{l_{i \tau}} & , \tau<65 \\
P O_{\tau}\left(R_{\tau-1}^{l} \cdot N D C_{i \tau-1}\right)+D B P O_{i \tau} & , \tau \geq 65 .
\end{array}\right.
$$

According to current Swedish tax rules, labour income and pension benefit are taxed at the same rate, and separate from capital income ${ }^{7}$. To calculate net income $-L_{i \tau}^{n}$, we first deduct a general allowance of 10; then a municipal tax of $30 \%$, a government tax of $20 \%$ on all income above 300 and finally an additional government tax of $5 \%$ on income above 450 . Net income is bounded below at 60 by the social welfare minimum-benefit, which also applies to retirees in the form of a governmentguaranteed minimum pension.

$$
\begin{aligned}
L_{i \tau}^{n}= & \max \left[L_{i \tau}-0.3 \max \left(L_{i \tau}-10 ; 0\right)-\right. \\
& \left.0.2 \max \left(L_{i \tau}-300 ; 0\right)-0.05 \max \left(L_{i \tau}-450 ; 0\right) ; 60\right] .
\end{aligned}
$$

All the threshold-values that create kinks in tax-rates and benefits ${ }^{8}$ are indexed to the expected national labour income growth- $\mu^{l}$, except the social welfare minimum benefit which is kept constant in real terms.

\footnotetext{
${ }^{7}$ We use the tax rules for incomes earned in 2003 .

${ }^{8}$ This is the same as in the US since the "bend points" when calculating the primary insurance amount (PIA) are adjusted by average earnings growth.
} 


\subsection{Assets}

There is one risky and one risk-free asset with after-tax real log-returns equal to $r_{\tau}^{e}$ and $r^{f}$ respectively. Excess return is defined as

$$
r_{\tau}^{e}-r^{f}=\mu^{e}+\eta_{\tau}
$$

where the noise $-\eta$, is correlated with the group aggregate innovation in permanent labour income $\xi_{k}$, which allows for a group specific sensitivity to the risky asset,

$$
\left[\begin{array}{l}
\boldsymbol{\xi} \\
\eta
\end{array}\right] \sim N\left(\left[\begin{array}{c}
-\frac{1}{2} \boldsymbol{\sigma}_{\xi}^{2} \\
-\frac{1}{2} \sigma_{\eta}^{2}
\end{array}\right],\left[\begin{array}{cc}
\boldsymbol{\Sigma} & \boldsymbol{\sigma}_{\xi \eta} \\
\boldsymbol{\sigma}_{\xi \eta}^{\prime} & \sigma_{\eta}^{2}
\end{array}\right]\right)
$$

\subsection{Private savings and consumption}

Each individual starts her "optimization life" with initial wealth set to $\digamma$. In pre-retirement years the individual receives a wage, and in subsequent years the individual will receive retirement benefits. The individual have two control variables: the proportion of cash on hand to consume $-\theta_{\tau}$, and what proportion of savings $-\alpha_{\tau}$, to allocate to the risky asset. The cash on hand, or disposable wealth, is therefore,

$$
X_{i \tau}=\left\{\begin{array}{cl}
e^{r^{f}}\left[1+\alpha_{i \tau-1}\left(e^{\left.\left.\mu^{e}+\eta_{\tau}-1\right)\right]\left[1-\theta_{i \tau-1}\right] X_{i \tau-1}+L_{i \tau}^{n}}\right.\right. & , \tau>\tau_{0} \\
\digamma_{i}+L_{i \tau}^{n} & , \tau=\tau_{0}
\end{array}\right.
$$

of which consumption is,

$$
C_{i \tau}=\theta_{i \tau} X_{i \tau}
$$

There is also constraints for both borrowing and short-sales,

$$
\begin{aligned}
& 0 \leq \theta_{i \tau} \leq 1 \\
& 0 \leq \alpha_{i \tau} \leq 1
\end{aligned}
$$




\subsection{Mandatory savings with Shiller-swaps}

With our proposal, the agent can exchange (buy the contract) the risk and return in their $N D C$ account for equity exposure, through a Shiller-swap. The design of this contract is as follows: first, we define the premium $-s$, to the seller of the contract; in such a way, that if a Shiller-bond existed, with $\log$-return- $\left(\mu^{l}+\xi_{\tau}^{A}+s\right)$, (equal to labour income growth plus premium) it would be a non-redundant asset; i.e., attracting an unrestricted (international) investor with power utility, i.e.

$$
\begin{gathered}
\mu^{l}+s=r^{f}-\frac{\sigma_{\xi^{A}}^{2}}{2}+\beta\left(\mu^{e}+\frac{\sigma_{\eta}^{2}}{2}\right), \\
\text { where } \beta=\frac{\operatorname{Cov}\left(\eta, \xi^{A}\right)}{\operatorname{Var}(\eta)} .
\end{gathered}
$$

We then create a zero-investment portfolio,

$$
E\left[e^{r^{f}}\left(e^{\mu^{e}+\eta_{\tau}}+\Lambda-1\right)-\Lambda e^{\mu^{l}+\xi_{\tau}^{A}+s}\right]=0
$$

which determines the exchange multiple $-\Lambda$; the ratio by which returns are swapped in a Shillerswap. The reason for this construct is that; we are only interested in the demand for Shiller-swaps due to the different risk characteristics and not because of differences in expected return,

The individual can now choose- $\lambda$, the proportion of their $N D C$ account they wish to swap. Consequently the overall return on the NDC account (Equation (2.5)) changes to

$$
R_{\tau}^{l}=e^{\mu^{l}+\xi_{\tau}^{A}}+\lambda\left[e^{r^{f}}\left(e^{\mu^{e}+\eta_{\tau}}+\Lambda-1\right)-\Lambda e^{\mu^{l}+\xi_{\tau}^{A}+s}\right]
$$

\subsection{Optimization}

The optimization problem therefore has four state-variables $(\tau, v, X$ and $N D C)$ and three choicevariables $(\theta, \alpha$ and $\lambda)$, as well as four stochastic variables $\left(\epsilon, u, \xi^{A}\right.$ and $\left.\eta\right)$. The value function of the individual intertemporal consumption and investment problem can then be written as

$$
\begin{gathered}
V_{\tau}\left(\Gamma_{\tau}\right)=\max _{\theta_{\tau}, \lambda_{\tau}, \alpha_{\tau}}\left\{\frac{C_{\tau}^{1-\gamma}}{1-\gamma}+\delta E_{\tau}\left[p_{\tau} V_{\tau+1}\left(\Gamma_{\tau+1}\right)+\left(1-p_{\tau}\right) b \frac{D_{\tau+1}^{1-\gamma}}{1-\gamma}\right]\right\} \\
\Gamma_{\tau}=\left\{X_{\tau}, v_{\tau}, N D C_{\tau}\right\} .
\end{gathered}
$$


The solution to this problem determines the state-dependent policy-rules

$$
\begin{gathered}
\theta_{\tau}=\theta_{k \tau}\left(\Gamma_{\tau}\right), \\
\alpha_{\tau}=\alpha_{k \tau}\left(\Gamma_{\tau}\right), \\
\lambda_{\tau}=\lambda_{k \tau}\left(\Gamma_{\tau}\right) .
\end{gathered}
$$

We solve the problem numerically by backward recursion from the final year- $T$, using by-now standard methods, cf. Cocco et al. (2005) and Judd (1998).

\section{CALIBRATION OF PARAMETERS}

\subsection{Estimation of labour income process}

We model individuals rather than households. Our rationale is primarily that: pension contributions and benefits are based on individual rather than family incomes; taxes are progressive and only dependent on the individual instead of family incomes. In addition to wages, labour income was defined to include all taxable social benefits, primarily compensation for unemployment, sickness and early retirement. Data was calculated from the LINDA data set for the years 1992 to 2002. LINDA - a register-based longitudinal data set, which consists of a large panel of individuals, which is representative for the population from 1960 and onwards. The data set covers 3.35\% of the Swedish population (more then 300,000 individuals plus their household members) and is described in Edin and Fredriksson (2000) and has recently received attention cf. Calvet et al (2006), Campbell (2006) and Flood (2003).

The data was divided into six non-intersecting groups defined by educational attainment and sex. The predictable component of labour income was estimated separately for each group and the regressors include dummy variables for marital status and age as well as the number of children in four age-intervals. Table A.1 presents some parameter estimates for the most numerous group - Men with High-school ${ }^{9}$

[skriv ngt mer]

\footnotetext{
${ }^{9}$ The results from the other groups are similar, and income in this group was closest to the national average. A more detailed description of the methodology and parameter estimates can be found in Carlsson and Erlandzon (2005).
} 


\subsection{Individual parameters}

For the reference case we used a standard set of assumptions regarding, the individual parameters. First, we set the coefficient of relative risk aversion $-\gamma$ to 5 and the discount factor- $\delta$ to 0.98 , and the bequest parameter - $b$ is set to 1 , making consumption and bequest equally important in the final year. The survival probabilities $p$ are sex dependent and taken from the Swedish life insurers when underwriting new policies, i.e. they are forward looking.

\subsection{Assets and correlations}

We set the risk-free aftertax rate $-r^{f}$ to $1.5 \%$, consistent with the present gross return of less than $2 \%$ for long-dated index-linked bonds. The mean after tax equity premium $\mu^{e}$ is set to $3 \%$, which is low when compared with the historical average, but corresponds well with forward-looking estimates Claus and Thomas (2001); Fama and French (2002)). Volatility $\sigma_{\eta}$ was set to $17 \%$ for the risky asset.

Following Cocco et al. (2005), we then estimated the correlation $\varrho_{\xi_{k}}$ between group-specific permanent labour income shocks $\xi_{k \tau}$ and lagged equity returns $\eta_{\tau-1}$.to estimate (cf. Table A.1). To keep the value of the $N D C$ account within "reasonable" limits, we arbitrarily restricted the equity exposure from the Shiller-swap to $\pm 20 \%$ of the account. We also set the growth in average labour income $\mu^{l}$ to $1.8 \%$, the estimate used by the Swedish National Social Insurance Board. Finally, initial wealth $\digamma$ was set to 47 , the mean wealth for individuals between the ages of 20 and 23 .

\section{RESULTS}

To study the potential outcomes generated by the model; we simulated individual behaviour from age 20, by generating 30,000 random trajectories through time. Subject to the stochastic experience, the individual will choose a response, defined by the policy functions in Equation (2.20) (shares of consumption, risky assets and Shiller swaps), that describe the optimal state dependent behaviour. 


\subsection{International pricing of Shiller-swaps}

As a reference, we plot the averages of the simulated trajectories for cash on hand (Figure A.9), risky weight (Figure A.8) and consumption (Figure A.7) for two scenarios; with and without the existence of an internationally priced Shiller-swap. Since the swap was priced as a zero-investment, we do not expect these profiles to be more than marginally different. However, the risk exposure of the $N D C$ account is completely changed. In the Figure A.6, we plot the profile for the average size of the $N D C$ account together with the hedged amount of aggregate wage risk for an internationally priced swap. Prior to mid-life the agent is constrained by our arbitrary rule of a maximum equity exposure in the $N D C$ account of $20 \%$. Before retirement, the individual hedge not only the $N D C$ account, but also the discounted expected value of both the defined benefit contract and future wages. When the defined benefit pension is fixed at retirement and future wages are zero, the agent still continues to hedge the discounted expected value of the $N D C$ account.

\subsection{Inter-generational pricing of Shiller-swaps}

To investigate the potential demand for Shiller-swaps from domestic investors only trading with their $N D C$ accounts as collateral, we increased the swap premium $-s$ (Equation (2.16)) with 10,15 and $25 b p$ (basis points) respectively, in addition to what an international investor requires. Figure A.3 (Shiller-swap share) and Figure A.10 (Shiller amount- $\lambda_{\tau} N D C_{i \tau}$ ) shows the simulated profiles, but now for the equity exposure that stems from the Shiller-swap. The additional premium will encourage the agent to be both a buyer and seller of such a swap, but at different ages. Before retirement, the individual will on average be a buyer of the Shiller-swap and afterwards a seller; thereby creating a voluntary inter-generational transfer of wage-growth risk. Selling the contract implies a negative equity exposure in the $N D C$ account, that is partly compensated for by a higher risky share $-\alpha$ in private savings (cf. Figure A.1)

[Insert fig A.3, A.10 and A.1 here]

The higher risky share does not fully compensate for the negative equity-exposure in the $N D C$ account, as is demonstrated in Figure A.2, which shows total equity exposure from both private 
savings and the $N D C$ account. In early life, the agent tries to maximise the equity exposure (subject to our constraint of $20 \%$ ), irrespective of the premium. Later in life and as private savings increase, the increased swap-premium make the agent more inclined to sell the Shiller-swap.

For the single agent belonging to this group and with these preferences (risk aversion); the $15 b p$ additional swap premium would approximately "clear" the demand and supply across the individuals age; increasing the premium further would create excess supply. We can therefore expect thatif overall demand and supply is unaffected by individual differences in risk-aversion - a Shiller-swap market could be established within the $N D C$ framework without resorting to an international market. Changing the relative risk aversion from 5 to 2 or to 10 has only a minor effect on preference for Shillerswap exposure ( $c f$. Figure A.5), whereas the same changes in risk aversion have a dramatic impact on the risky weight ( $c f$. Figure A.4).

[Insert fig A.5 and A.4 here]

As long as individuals are risk-averse, and with the expected risk premium $-s$ and multiple $-\Lambda$, set so that the Shiller-swap has zero expected return ( $c f$. Equation (2.17)), there will still be demand for the Shiller-swap, but for hedging perspective; whereas the demand for risky assets are primarily motivated by higher expected returns.

\section{CONCLUSION AND COMMENTS}

In a life-cycle model of a borrowing-constrained individuals' consumption- and portfolio-choice in the presence of uncertain labour income and realistically calibrated tax and pension systems - where the pension scheme consists of both a defined benefit and notionally defined contribution parts, the latter indexed to stochastic aggregate labour income growth. The introduction of a Shiller-swap to mandatory individual pension accounts would allow individuals to beneficially swap wage- and equityrisk.

Although such a market has not yet been established, an increase in the premium of only $15 b p$ would create domestic demand and supply for this swap, by individuals at different ages. It would therefore be possible to create such a market among individuals within the pension system, thereby 
allowing a voluntary inter-generational sharing of wage-risk.

\section{REFERENCES}

Calvet J.E., J.Y. Campbell and P. Sodini, 2006, Down or Out: Assessing the Welfare Costs of Household Investment Mistakes, working paper NBER No. 12030.

Campbell J.Y., 2003, Investment Risk and Social Security Reform Public Policy Panel, American Finance Association.

Campbell J.Y., 2005, Risksharing in Pensions Systems, working paper, Harvard University.

Campbell J.Y. and Y. Nosbusch, 2006, Intergenerational Risksharing and Equilibrium Asset Prices, working paper, Harvard University.

Campbell J.Y., 2006, Household Finance, Journal of Finance 18, 535-567.

Campbell J. Y., J. Cocco, F. Gomes and P. Maenhout, 2001, Investing Retirement Wealth: A life-cycle Model, in John Y. Campbell and Martin Feldstein(eds), Risk Aspects of Social Security Reform, The University of Chicago Press, Chicago, IL.

Carlsson E. and K. Erlandzon, 2005, The Dark Side of Wage-Indexed Pensions, working paper, School of Business, Economics and Law, Göteborg University.

Cocco J.F, 2005, Portfolio Choice in the Presence of Housing, Review of Financial Studies 18, 535-567.

Cocco J.F, F.J. Gomes and P.J. Maenhout, 2005, Consumption and Portfolio Choice over the LifeCycle, Review of Financial Studies 18, 491-533.

Carroll C. D., 1997, Buffer-Stock Saving and the Life-Cycle/Permanent Income Hypothesis, Quarterly Journal of Economics 112, 1-55.

Carroll C. and A. Samwick, 1997, The Nature of Precautionary Wealth, Journal of Monetary Economics 40, 41-71. 
Claus, J. and J. Thomas, 2001, Equity premia as low as three percent? Evidence from analysts' earnings forecasts for domestic and international stock markets, Journal of Finance 61, 1629-1666.

Commission to Strengthen Social Security, 2001, Strengthening Social Security and Creating Wealth for all Americans, Report of the President's Commission, www.csss.gov.

Deaton, A. 1991, Saving and liquidity constraints, Econometrica 59, 1221-1248.

Diamond, P.A., 2002, Social Security Reform ( Lindahl Lectures), Oxford University Press Inc, New York, NY.

Edin, P. and P. Fredriksson, 2000, Longitudinal INdividual DAta for Sweden, working paper 2000:19, University of Uppsala.

Fama E.F. and K.R. French, 2002, The Equity Premium, Journal of Finance 62, 637-659.

Flood, L.R. 2003, Can we afford the future? An evaluation of the new Swedish pension system, working paper, School of Business, Economics and Law, Göteborg University.

Friedman M, 1957, A Theory of the Consumption Function, Princeton Univ. Press, Princeton

Gomes F. and A. Michaelides, 2005, Optimal Life-Cycle Asset Allocation: Understanding the Empirical Evidence, Journal of Finance 60, No. 2, 869-904

Gourinchas P-O. and J.A. Parker, 2002, Consumption over the life-cycle, Econometrica 70, 47-89

Holzmann R. and E. Palmer, 2006, Pension Reform: Issues and Prospects for Non-Financial Defined Contribution (NDC) Schemes, World Bank, washington D.C.

Judd K.L.,1998, Numerical Methods in Economics, MIT Press, Cambridge, MA.

Merton R.C., (1971), Optimum Consumption and Portfolio Choice in a Continuous-Time Model, Journal of Economic Theory, 3, 373-413.

Modigliani, F. and R. Brumberg, 1954, Utility Analysis and the Consumption Function: An Interpretation of Cross-section Data, in K. Kurihara, editor, Post Keynesian Economics, Rutgers University Press, New Brunswick, NJ. 
Riksförsäkringsverket RFV, 2002, The Swedish Pension System Annual Report 2002, www.forsakringskassan.se

Samuelson P.A., 1969, Lifetime Portfolio Selection by Dynamic Stochastic Programming, Review of Economics and Statistics 51, 239-246.

Schieber S.J. and J.B. Shoven, 1996, Social Security Reform: Around the World in 80 Ways, American Economic Review 86, 373-77.

Shiller R.J., 1993, Macro Markets: Creating institutions for managing society's largest economic risks, Oxford Univeristu Press, Oxford, U.K..

Shiller R.J., 2003a, The New Financial Order: Risk in the 21st Century, Princeton University Press, Princeton, NJ.

Shiller R.J., 2003b, Social Security and Individual Accounts as Elements of Overall Risk-Sharing, American Economic Review 93, 343-347.

Shiller R.J., 2005, The Life-cycle Personal A Proposal for Social Security: An Evaluation, working paper, NBER .

Viceira L., 2001, Optimal Portfolio Choice for Long-Horizon Returns with Non-Tradable Labor Income, Journal of Finance 46, 433-70. 


\section{APPENDIX A: TABLES AND FIGURES}

TABLE A.1

Variance decomposition and estimated return covariances

\begin{tabular}{|c|c|c|c|c|c|}
\hline Group & $\begin{array}{l}\text { Number of } \\
\text { individuals }\end{array}$ & $\begin{array}{c}\text { Estimated } \\
\text { variance of } \\
\text { the permanent } \\
\text { component, } \sigma_{u_{k}}^{2}\end{array}$ & $\begin{array}{c}\text { Estimated } \\
\text { variance of } \\
\text { the transitory } \\
\text { component, } \sigma_{\varepsilon_{k}}^{2}\end{array}$ & $\begin{array}{c}\text { Std. } \\
\text { of the permanent } \\
\text { aggregate } \\
\text { component, } \sigma_{\xi_{k}}\end{array}$ & $\begin{array}{c}\text { Correlations } \\
\text { with Swedish } \\
\text { equity returns, } \\
\varrho_{\xi_{k} \eta}\end{array}$ \\
\hline Full sample & 55532 & & & .01989 & .482 \\
\hline Men & 31540 & & & & \\
\hline $\begin{array}{c}\text { Compulsory } \\
\text { school }\end{array}$ & 6878 & $\begin{array}{r}.00462 \\
(.000137)\end{array}$ & $\begin{array}{r}.00867 \\
(.000379)\end{array}$ & .02008 & .517 \\
\hline $\begin{array}{l}\text { High school } \\
\text { (gymnasium) }\end{array}$ & 14978 & $\begin{array}{r}.00564 \\
(.000112)\end{array}$ & $\begin{array}{r}.00981 \\
(.000313)\end{array}$ & .02020 & .514 \\
\hline $\begin{array}{l}\text { University } \\
\text { degree }\end{array}$ & 9684 & $\begin{array}{r}.00958 \\
(.000226)\end{array}$ & $\begin{array}{r}.01208 \\
(.000625)\end{array}$ & .02187 & .539 \\
\hline Women & 23992 & & & & \\
\hline $\begin{array}{c}\text { Compulsory } \\
\text { school }\end{array}$ & 3485 & $\begin{array}{r}.00403 \\
(.000140)\end{array}$ & $\begin{array}{r}.00623 \\
(.000386)\end{array}$ & .02014 & .477 \\
\hline $\begin{array}{l}\text { High school } \\
\text { (gymnasium) }\end{array}$ & 11119 & $\begin{array}{r}.00460 \\
(.000085)\end{array}$ & $\begin{array}{r}.00741 \\
(.000235)\end{array}$ & .01943 & .444 \\
\hline $\begin{array}{c}\text { University } \\
\text { degree }\end{array}$ & 9388 & $\begin{array}{r}.00634 \\
(.000126)\end{array}$ & $\begin{array}{r}.01000 \\
(.000348)\end{array}$ & .02269 & .290 \\
\hline
\end{tabular}




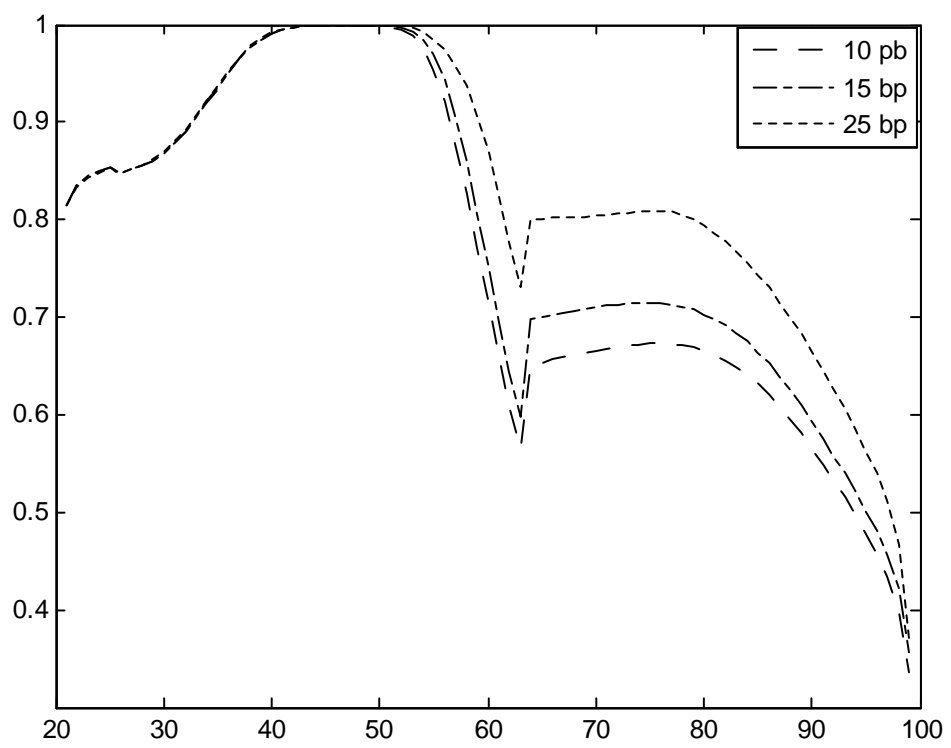

FIG. A.1 Risky weights of cash on hand $-\alpha_{\tau}$ with different Shiller-swap premia in addition to the international requirement- $s$.

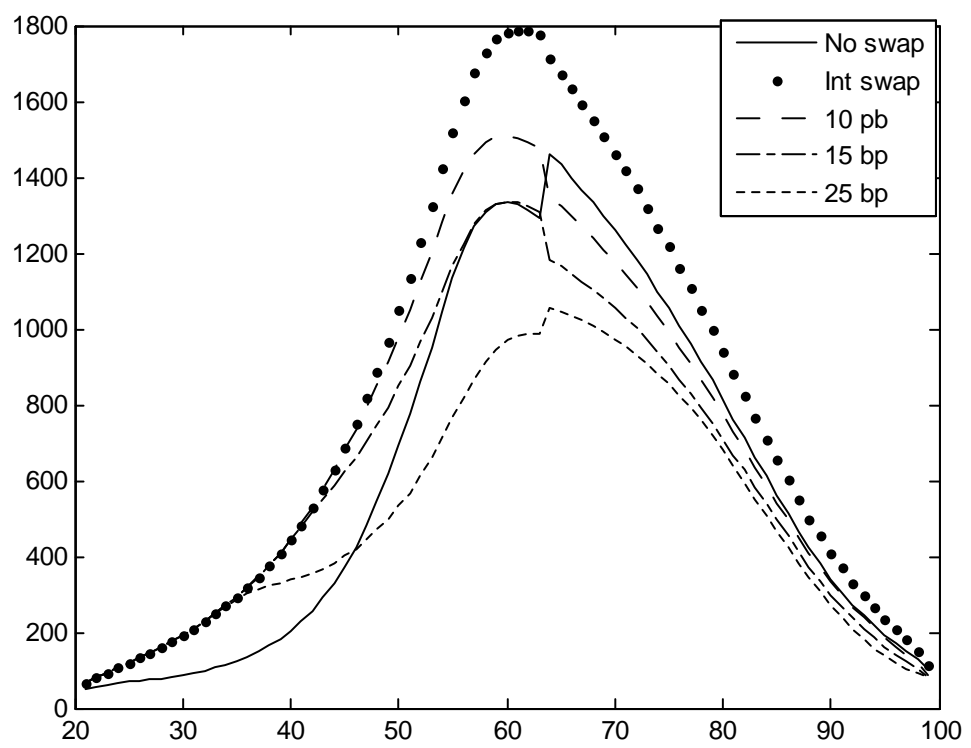

FIG. A.2 Total exposure to risky assets from private savings and the $N D C$ account. 


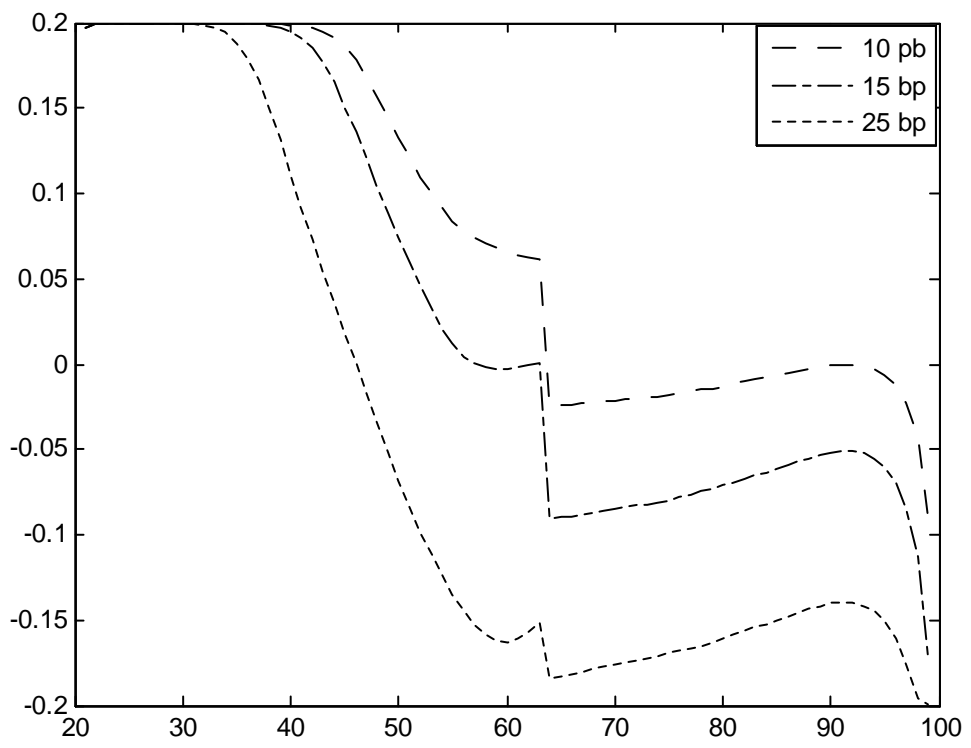

FIG. A.3 Shiller-swap weights $-\lambda$ with different swap premia in addition to the international requirement- $s$.

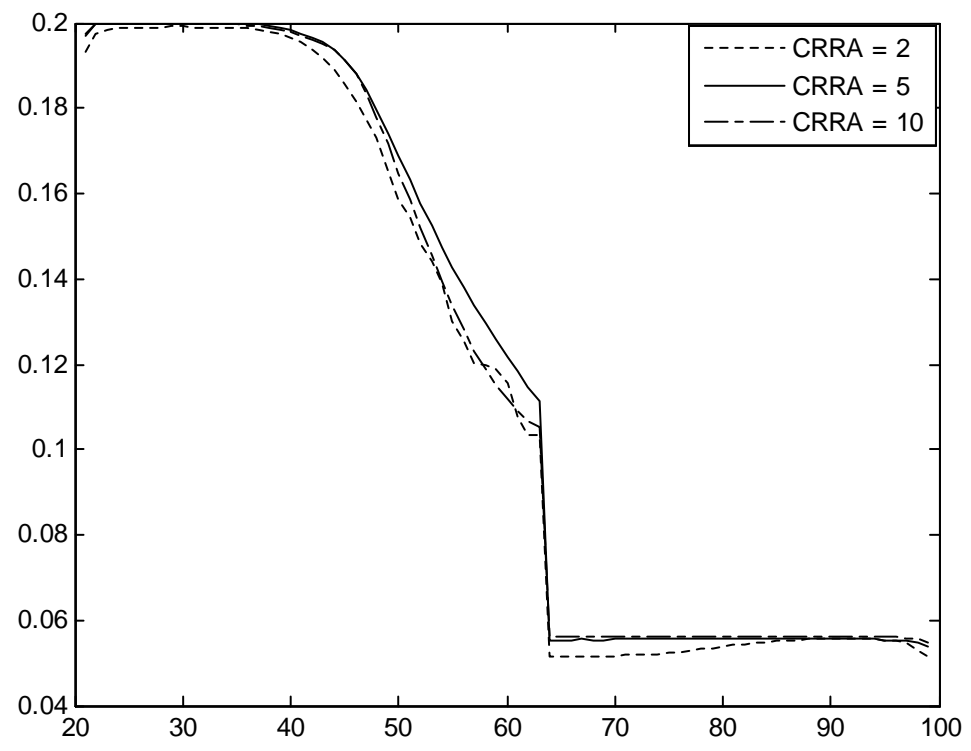

FIG. A.4 Shiller-swap weights $-\lambda$ when swap premium is set for international investors, but with different constant relative risk aversions $(\mathrm{CRRA})-\gamma$. 


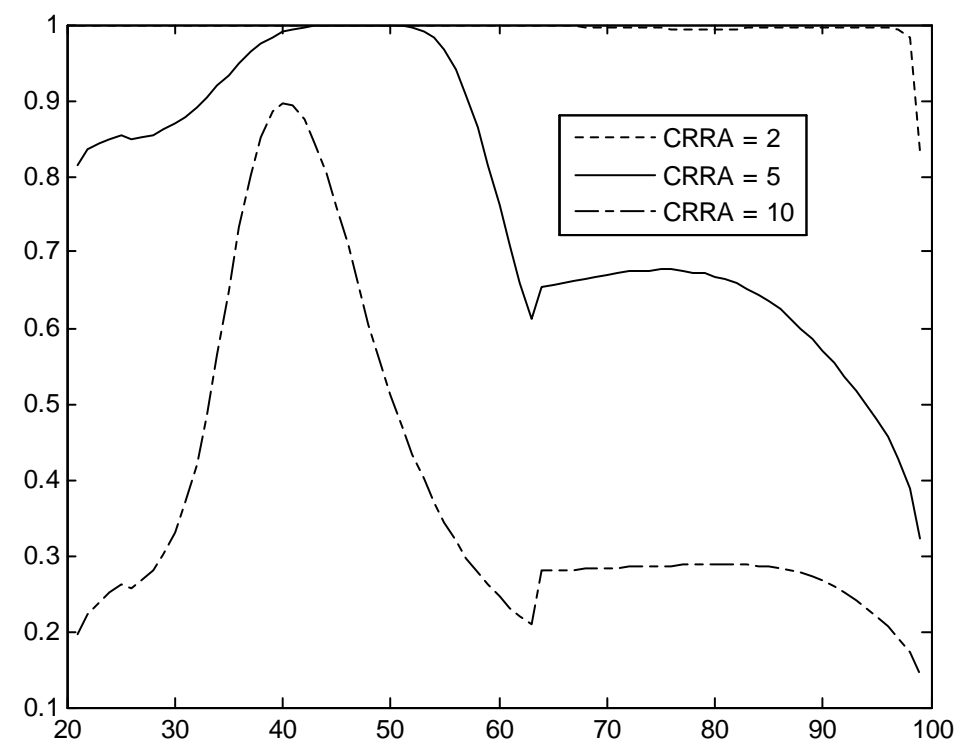

FIG. A.5 Risky weights when swap premium $-s$ is set for international investors, but with different constant relative risk aversions $(\mathrm{CRRA})-\gamma$.

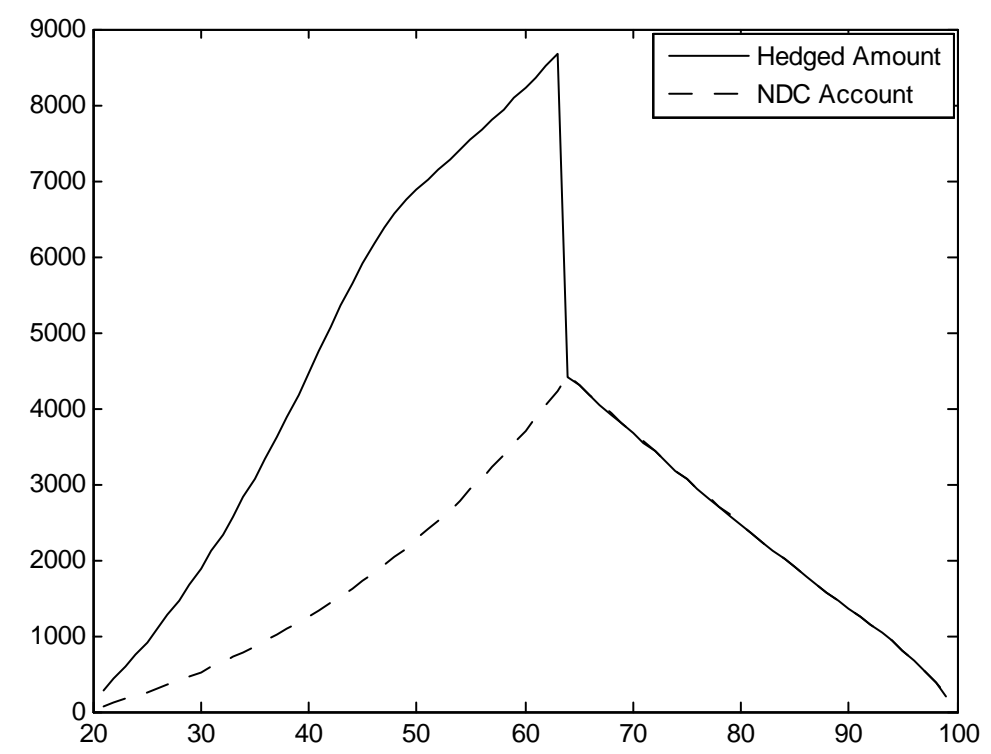

FIG. A.6 Hedged wage exposure $-\Lambda \lambda_{\tau} N D C$ and value of $N D C$ account, when the swap premium is set for international investors. 


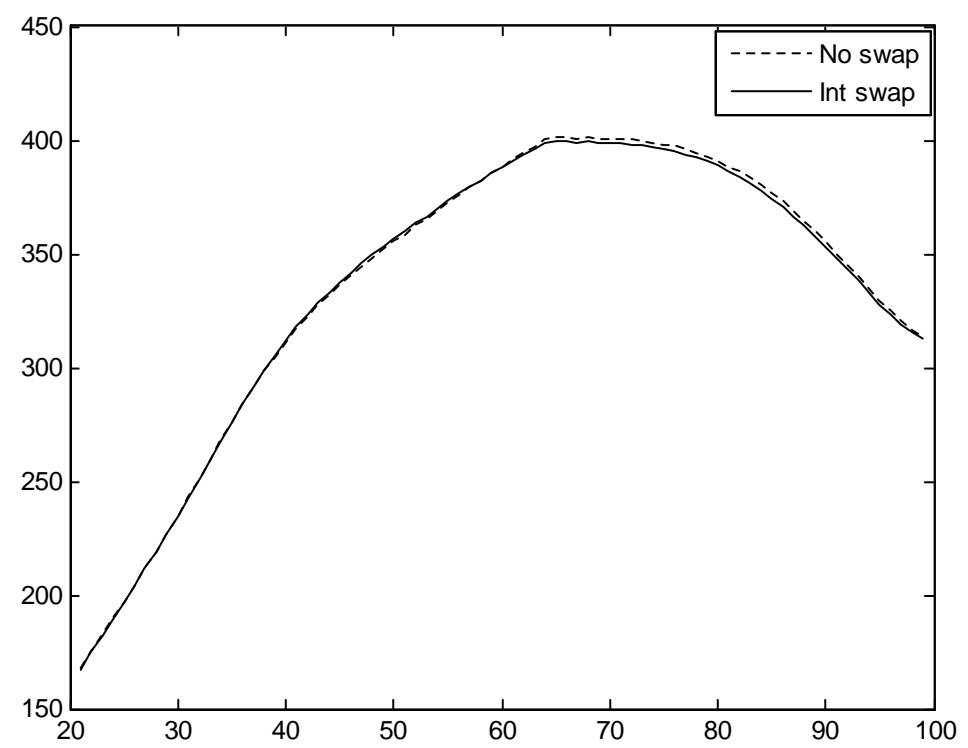

FIG. A.7 Consumption $-C$, patterns when swap premium is set for international investors and without Shiller-swaps.

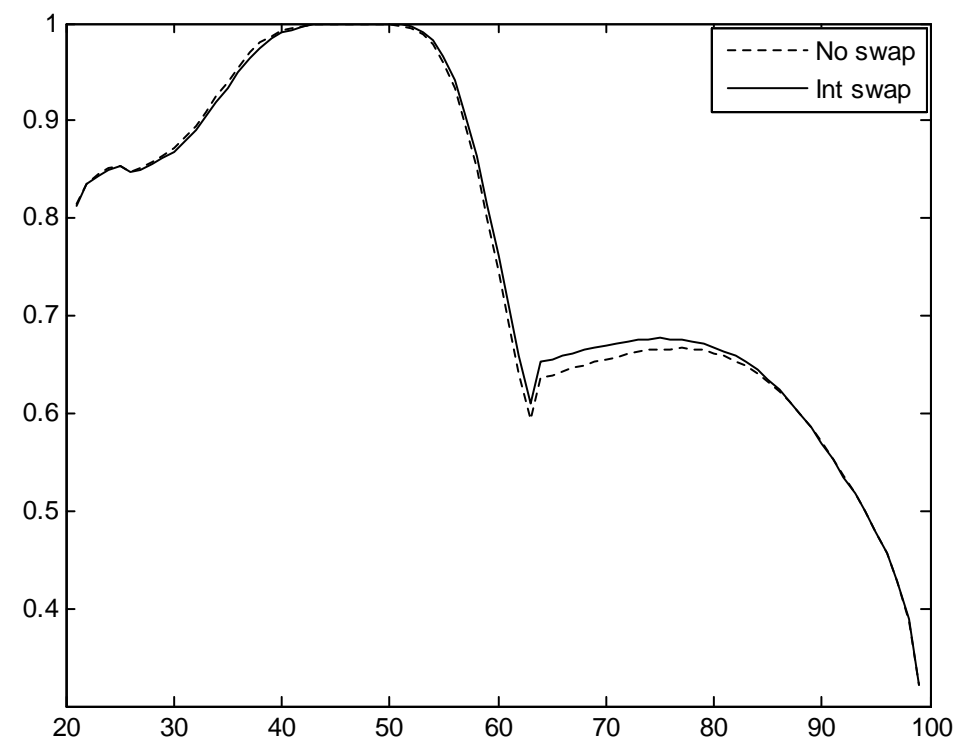

FIG. A.8 Risky weight $-\alpha_{\tau}$ when swap premium is set for international investors and without Shillerswaps. 


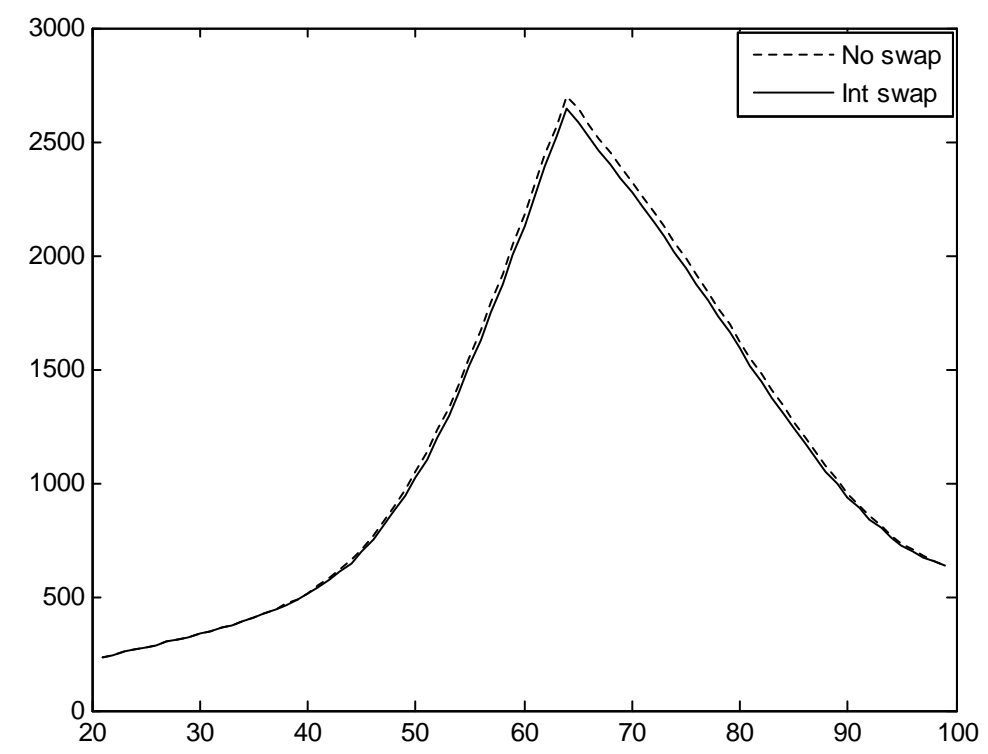

FIG. A.9 Cash on hand $-X$, patterns when swap premium is set for international investors and wihout Shiller-swaps.

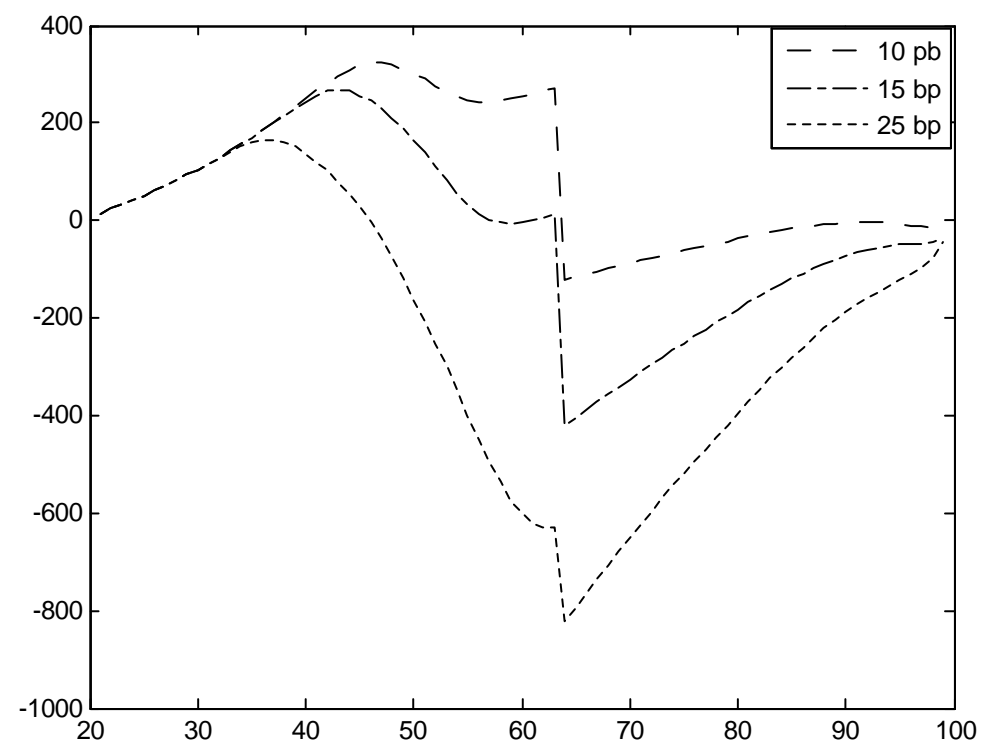

FIG. A.10 Amount of equity exposure through Shiller-swap $-\lambda_{\tau} N D C_{\tau}$, with different swap premia. 